\title{
Natalia Ginzburg: The Fabric of Voices
}

\section{Donald Heiney}

In the early years of the fascist era Natalia Ginzburg, the daughter of a Jewish university professor, lived in Turin in an intellectual and eccentrically bourgeois family with socialist tendencies. This milieu, which in retrospect seems exactly suited to her needs and talents, she regarded as totally unpromising for a writer. She read chiefly Chekhov and other foreign authors, intent not so much on style or theme as on the power of fiction to create modes of reality different from her own: "invisible protectors and interlocutors . . . whose books I didn't read, but rather sucked as a baby sucks the nurse's milk, trying to absorb and penetrate the secret of the prose." This secret was involved most of all with the creating of a poetic ambience, and the ambience was Petersburg, the Nevsky Prospekt, the nebulous and oblique mysteries of the Russian soul. Conscious of her own total deficiency in these matters, she began in absolute humility to write fiction, expecting nothing of herself and "dumbfounded with pride and astonishment" when she managed after some years of effort to finish her first story. In this way, setting one word after another in the only way it seemed possible for her to set words one after the other, in three decades of work she produced a full-scale novel and five short ones, a number of stories, the "family autobiography" Lessico familiare, a volume of essays, and a quantity of sketches and miscellaneous pieces. These thirty years were beset by the most anguishing kind of personal tragedy: her family was dispersed by the war, the first husband Leone Ginzburg murdered by the Nazis, her close friend Pavese took his own life. Yet her writing, as intimately personal as it is, never touches on these things or mentions them only in passing, and it never loses its good humor in spite of the omnipresent vein of melancholy. She is a tragic humorist, as Kafka has been described as a religious humorist.

Because of her immature urge to be a Russian or some kind of foreign writer, her early work is curiously abstract; the setting is placeless and timeless and the characters have no surnames. As it develops her fiction becomes gradually more specific and personal and at the same time less fictitious; she moves from imitations of Chekhov to a fiction that is indistinguishable from autobiography. Yet from the beginning all her narrative is recounted by the same voice. The voice is feminine and fundamentally that of the author, even though it is attributed in the early fiction to narrators very different from Natalia Ginzburg and simultaneously expressive of these characters. The voice plays over and defines the surface of the narrative, and breaking through to this surface, interwoven with it, are the voices of other characters who are soon perceived as recurring from one 
story to the next, in a kind of modal counterpoint. Almost without exception her writing is about families. There is a recurrent note of ending; families are fragile things, dispersed by war and deteriorating of their own accord through death, through marriage, through the desire of the children for freedom. The archetypal title of her work is the title of one of her short novels, Le voci della seravoices from the penumbra faintly melancholy and yet resilient and accepting, voices transcribed utterly without sentiment even in their pettiness and occasional malice. She is particularly a specialist on relations between parents and children, on the affections that hold them together and are at the same time balanced by the antagonisms and struggles that hold them apart, and on the complicated, ambivalent, quasi-sexual and yet chaste relations between brother and sister. In her narrative the family is neither a happy nor an unhappy institution. It simply is, and the people in it are sometimes happy and sometimes unhappy. When the narrating voice is happy it is frequently humorous, and when it is unhappy it regards the situation with irony. In place of Italian lamenting or Jewish lamenting there is a kind of French and existentialist pessimism of acceptance. There are echoes of Proust, or Svevo, of Isaac Babel; psychological coincidences rather than influences, except perhaps in the case of Proust.

There is no question that this ironic manner of regarding the world is an inherited trait or at any rate derived from her family. Her father held the chair of anatomy at the University of Turin and was one of Italy's most eminent scientists, but he was an amiable cynic who was unable to take himself totally seriously. During the antisemitic campaign in 1938 he happened to receive a form on which he was asked to note any honors or special merits he had achieved in his lifetime, and wrote down that he had once swum in the Po in midwinter, adding, "On the occasion of certain works effected in my house, the Engineer Casella appointed me foreman." His private passion was mountaineering, a sport he inflicted as well on his family and associates, and he had a contempt for weakness either physical or moral. It was self-indulgent to complain of hunger or thirst in the mountains, it was "flamboyant" to wear city shoes in the mountains, to stop at chalets for lunch, to carry cognac or sugar-cubes into the mountains, to wear a waterproof raincoat. One small boy, to whom it was explained that one didn't complain of thirst in the mountains, was later heard remarking, "I'm thirsty but I'm not saying so." This perky and slightly rebellious stoicism is the ethical thread of all of Natalia Ginzburg's work. The mother is as much a source of this toughness as the father. For the mother in Lessico familiare "Wash your face in cold water" is a remedy for all-fascism, unrequited love, the frailty of the flesh, the Human Condition. The tribal toughness is assertive and cranky in the male, resilient, intuitive, and conceding in the female. The family is presented totally without sentimentalism. Like a pride of lions they are held together by powerful biological forces, yet each is wary and self-contained, skeptical of the others, ironic of the father's claim to dominance but conceding to power after the first ritual scratches. The family forms through marriage and birth, consolidates, then gradually disintegrates. Commonly the narrator is a semi-spectator in this process; particularly in Valentino, Sagittario, and Lessico familiare she takes only a peripheral part in the drama and her primary function is to record the voices of others. 
Natalia Ginzburg only reluctantly writes about herself, even in the book that purports to be a kind of autobiography. Yet everything she writes reveals herself intimately in the way that all honestly written fiction, even something so ostensibly objective as Madam Bovary, reveals its creating consciousness in the manner and implication of its telling. And Natalia Ginzburg has no pretensions to this kind of objectivity; with a quite cheerful humility she confines herself to the small scale of her own knowledge and observation. She is a kind of compassionate tape-recorder, and one that filters language so as to allow only a subtly chosen pattern of assonances to arrive at the ear of the listener.

The voices of the family resemble each other and yet are distinctive. They flow in a way that is apparently unstudied, as the bird sings and the fish swims; each voice speaks for itself and yet the whole forms a pattern of interlocking polyphonies. To borrow a recurring adjective in Natalia Ginzburg, the voices are intrecciate, woven together in the way that a girl braids her hair. To begin with the girl's hair is one thing, then it is separated into strands, then the strands are woven in a pattern until they become one thing again, but a different kind of thing. Before the process the hair is spontaneous and unstudied nature; after the process it is art. (In defense of this rather elaborate metaphor it can be pointed out that styles of hair, especially in women, are significant to Natalia Ginzburg, and her character descriptions are full of terms for ways of arranging the hair: ciuffo, treccia, frangia, ricciolo). A typical dialogue in Le voci della sera begins as the narrator's fiancé Tommasino comes to visit the family, including the father, the mother, and a certain Aunt Ottavia. The conversation is entirely about relatives, chiefly those of the mother and aunt. From the mother's brother Cesare it passes to Cousin Ernesto, who was beaten by the fascists and put in jail, and finally died, the poor fellow, and to his daughter who had a splendid voice and went to America and sang in all the grand theatres. "Then, suddenly, she lost her voice. Now she can't even sing the Hymn of Garibaldi." Aunt Ottavia explains that this was because she was in a fire. "The hotel burned one night, and they wanted her to jump out the window, and everyone shouted for her to jump, and she just stayed there straddling the windowsill and didn't jump. And then she jumped, because down below, you see, they had put a safety-net. She jumped, but she lost her voice." Partly the fear and partly the smoke, puts in the mother. "Now however," persists Aunt Ottavia, "she has consoled herself by marrying a dentist." The mother goes on weaving the braid, which both know by heart. "Because after she lost her voice, she went practically mad from grief and she was confined in a hospital. And there, once a week, a dentist came round to look at the patients' teeth. So he fell in love with her. She had a beautiful mouth." The father is impatient with this rigamarole. "This story you've told me a million times. And what do you think Tommasino cares about it, people he's never laid eyes on and never will?" "We're just talking a little," explains the mother unperturbed. "Do you want us to just sit here staring at each other? You tell things, you talk. Chi dice una cosa, chi un'altra." In this way, one saying one thing and one another, the fabric of the narrative gradually takes form and assumes intricacy. The father's irritated barking is a counterpoint; the narrator and Tommasino are semi-involved spectators who, in spite of their silence, manage some- 
how to convey their combination of exasperation and resigned indulgence toward this sextet from Lucia in which everybody sings something different and yet, helter-skelter, all together end by making one thing. Somehow too-Natalia Ginzburg's art works by somehows-the reader as well is drawn into this tissue of he saids and she saids, until his exasperation and his indulgence merge with that of the story-telling voice.

$E$ stato cosi, an early short novel, begins with a pistol-shot in the manner of Simenon. Natalia Ginzburg gropes for a manner and tentatively takes up the roman-policier, but soon falls into the voice that threads its way through her work from its earliest stories. Setting out to explain why she shot her husband, the narrator is soon busy constructing the pattern of secondary voices that complicate and sustain the story. She begins telling how, living alone in a boarding-house, she had found herself courted by the somewhat dubious Alberto, whom she had met at the house of her friends Dr. and Mrs. Gaudenzi. Alberto for years has been conducting an affair with another woman; he comes and goes, never speaks of love to her, and disappears for weeks on end. But the narrator is lonely and there are no alternatives. "And so I fell in love with him, while I waited for him sitting in my boarding-house room with my face made up and the half-hours and hours went by and you could hear the peacock's cry and while I walked through the city looking always to see if he might be passing by, and my heart trembled every time I saw a little man with a white raincoat and one shoulder higher than another." The peacock's cry is a characteristic touch. It has nothing to do with anything, except perhaps that it contributes to mood like the breaking harp-string in The Cherry Orchard. Her work is full of such insignificant details that are somehow significant. The story-telling consciousness is easily distracted; when its eye falls on something of a curious shape, or even the most ordinary of objects, it often loses the thread or seems to. After some days of waiting, the narrator of $\vec{E}$ stato cosí makes up her mind to go to the Gaudenzis to see if they have any news of Alberto. "The doctor wasn't there, only his wife who was washing windows. I stayed watching how she polished the glass and she explained to me that you start with newspapers and ashes dissolved in water and then rub very lightly with a woolen rag and a shine appears that is a marvel. Then she came down from the ladder and made chocolate for me but she didn't tell me anything so I went away."

The naivete of the story-telling voice in this novel and in La strada che va in città, dating from 1946-47 and 1941 respectively, develops into a kind of sibylline and oblique simplicity in Tutti i nostri ieri (1952) and Lessico familiare (1963), without losing either its freshness of diction or its fundamental innocence. One of the more intricate aspects of her work is the relation of this voice to the sub-voices of the secondary characters-the particular manner of the weaving of the braid, and there are several. Sometimes, especially in the earlier fiction and in Lessico familiare, a conventional dialogue-form is employed, with quotation marks and paragraphing. At other times and particularly in Le voci della sera (1961) a kind of dixit device is used, borrowed with a perceptible suggestion of tongue-in-cheek from the epic. Characteristic remarks, made not at any particular 
time but simply typical of the character and embedded in the family consciousness, are presented in a kind of litany punctuated with dice or diceva:

Says my mother:-I got a crick in my neck, I don't know how. It couldn't have been the wind; it must have been that I turned around too quickly, when the peasant-woman called me.

She says:-This new peasant-woman of ours, I can never remember her name, is called Drusbalda. They have funny ideas about names in the country.

She says:-they seem all right. Still they're not too clean. The house, I noticed, wasn't too clean. They offered me coffee and it turned to vinegar in the stomach. will.

-Because the cup wasn't clean. I drank it against my

-One of these days, she says, I want to go to Giuliana's, and see the tea-pot.

She says:-How do you suppose Giuliana managed to get married, the stupidest of all the sisters?

She says:-It's always the stupid ones that manage to get married. The best girls don't find anybody.

One remark suggests another, the crick in the neck leads with a devious inevitability to the marrying of daughters. Chi dice una cosa, chi un'altra; except that in this case the character conducts a dialogue with herself.

A somewhat more intricate dialogue form is a kind of erlebte Rede in which the primary narrating voice, while retaining its own timbre and its particular irony towards events and characters, descends to assume at least partially the rhythm and speech-pattern of the character whose remarks are reported. The mother in Sagittario has an abrupt, impulsive, and somewhat violent manner of speaking; she is a foolish person who seeks to conceal her foolishness through assertiveness. The narrator herself has a calmer and more controlled way of telling her story, in longer sentences. But as she begins to recount her mother's hostility to the sister Giulia the one voice merges imperceptibly into the others.

Here at Dronero, before she got sick and now after her sickness, my sister did nothing all day long. Now and then she got up from her armchair, put the leash on the dog and with our little cousin Costanza took a walk around the house. The life of an old woman of ninety, my mother said. How could she ever get an appetite? And my mother had not yet succeeded in finding out whether Giulia liked living in the city. She requested me to ask her. She wouldn't ask her. She wouldn't ask her because Giulia's answers were always the same: a droop of the eyelashes, a shake of the head, a smile. And my mother was fed up with these answers. Even I didn't give her very much satisfaction with my answers, she said, and she never succeeded in finding out anything about me either. But at least I had an intelligent 
face, a face in which you could read something. Whereas Giulia the poor thing was an idiot. You couldn't read anything in her face.

When she made that little smile of hers, my mother felt like hitting her.

The two voices are kindred but distinctive. Yet their distinctiveness is not evident in any clear line of demarcation, a point at which it is evident that the daughter stops talking and the mother begins. Instead there is a gradual merging, a blending, from one voice to the next; the identities of the narrative are never discretely and totally delineated. In fact the hidden explanation of this narrative mode is that the mother never really does speak at all. None of the secondary characters do; we hear them only in the mimetic voice of the narrator, a voice at once ingenuous, unstudied, led by chance association from one subject to another in an apparently aimless way, and yet masterfully plastic and ventriloquent. The whole narrative oeuvre of Natalia Ginzburg, seemingly so rich in character, actually resides in the consciousness of this single narrator, the possessor not only of a keen auditory memory but of an extraordinary and flexible talent for mimicry.

The dixit device is not the only Homeric borrowing in Natalia Ginzburg. There is a suggestion of the epic manner as well in this way of dipping downward into the voice of a character and then rising again to regard the flow of narrative with detachment. If there were a female Homer, she would not be Homer but different from Homer: concerned with daily life rather than battles, penetrating to subtleties where the heroic poet hews giants, ironic or even whimsical about the world of men and its pretensions, yet resembling Homer in the combination of intimacy and detachment in the narrating voice. Natalia Ginzburg would be capable of recounting the parting of Hector and Andromache, perhaps, not Achilles chasing Hector around the walls, which would turn into a comedy like that of Cousin Ernesto's daughter straddling the windowsill. The world of her body of narrative is a feminine world. It is a world in which tea-pots and the making of babies are important but politics, business, and war are not; or, more precisely, in which politics, business, and war are recognized as affecting the destinies of all, but not susceptible of feminine control, and therefore viewed with a combination of indifference and irony that rescues the narrating ego from total impotence. To be ironic about a power over one's destiny is no longer to be totally in the control of that power. The narrating consciousness takes refuge in a world of trivia, but the trivia are in some way elevated to the archetypal. Furniture, family quarrels, broken engagements, bicycles, the way of washing windows: the tiny details, massed together and linking one by one, begin finally to form vague metaphysical shapes. The dominant shape that emerges, subsuming and strengthening the others, is a recognition of the tragic sense of life, a pessimism relieved by good humor. "If Stalin comes to take away my servant, I'll slay him," declares the mother in Lessico familiare. "How could I get along without my servant, I who don't know how to do anything?" But she will "get along" somehow, she and her daughters and the whole world of women with its resilience and its fundamental sources of renewal. The great of the earth had better watch out, because even beaten to defeat these family links, instincts, routines, attachments, repetitions, will inevitably begin to form again. The obscure force 
that holds together brother and sister, part jealousy and part affection, a hatred at its roots, is a persistence that transcends politics. Things are simple on the surface and complicated underneath. A story, too, should be simple on the surface and complicated underneath, and all the difficulty of art lies in this illusion.

Natalia Ginzburg

A Summary Bibliography

All copyright Giulio Einaudi Editore, Turin

La strada che va in città. Short novel, 1941.

È stato cosí. Short novel, 1947.

Valentino. Short novel, 1951.

Tutti i nostri ieri. Novel, 1952.

Sagittario. Short novel, 1957.

Le voci della sera. Short novel, 1961.

Le piccole virtú. Essays and sketches, 1962.

Lessico familiare. "Family autobiography," 1963.

Cinque romanzi brevi. Collection, 1964. (Includes La strada che va in città, É stato cosí, Valentino, Sagittario, Le voci della sera, and four stories).

Natalia Ginzburg $\quad T W O \quad S K E T C H E S \quad$ Translated by Donald Heiney

\section{My Psychoanalysis}

Once I resorted to psychoanalysis. It was summer, just after the war, and I was living in Rome. It was a sultry dusty summer. My analyst had an apartment in the central district. I went to him every day at three. He himself would open the door (he had a wife, but I never saw her). In his office it was shadowy and cool. Dr. B. was an elderly man, tall and bald, with a ring of silvery curls around the nape of his tanned neck, a small dark mustache, high and rather narrow shoulders. His shirt was always immaculate, with the collar open. The extreme neatness of his shirts and the cool shadow of his office were the things 